\title{
Therapeutic Benefits and Applications of Whey Protein
}

\author{
Mahmoud E. Ahmed ${ }^{1}$, Ahmed M. Hamdy ${ }^{1 *}$ and Ahmed R. A. Hammam ${ }^{1,2}$ \\ ${ }^{1}$ Dairy Science Department, Faculty of Agriculture, Assiut University, Assiut, Egypt \\ ${ }^{2}$ Dairy and Food Science Department, South Dakota State University, \\ Brookings 57007, SD, USA \\ *Corresponding author
}

\section{A B S T R A C T}

\section{Keywords}

Whey protein, therapeutic benefits; sweet whey, acid whey

\section{Article Info}

Accepted:

05 June 2020

Available Online:

10 July 2020
Whey protein is a derived by-product from cheese manufacturing and has many health benefits due to its high-level content of bioactive peptides, such as $\beta$-lactoglobulin, $\alpha$-lactalbumin, serum albumin, immunoglobulin, and lactoferrin. These proteins have antioxidant characteristics that reduce hypertension, cancer, hyperlipidemia, and virus contagious. In addition, whey protein is utilized to lessen the inflammatory bowel disease. In this review, we highlighted the characteristics, applications, functional properties of whey proteins.

\section{Introduction}

Whey is a by-product which is produced during cheese making by coagulating the milk by acid or enzymes. The typical composition of bovine milk (Table 1) has approximately $3.5 \%$ protein (about $80 \%$ of the protein content is casein, while $20 \%$ is whey proteins).

Whey proteins have a high nutritional value, and its composition varies based on the coagulation method (acid or enzymes). However, the composition of the final product is similar which has > 90\% water (Table 2). Using advanced technology, such as membrane filtration led to the manufacturing of different whey products (Yalcin, 2006; Guo and Wang, 2019a) (Table 3).

Whey is a good source of bioactive peptides, which are produced from whey by enzymatic hydrolysis during fermentation and gastrointestinal digestion. These bioactive peptides are utilized widely to improve human health and have inevitable roles, such as anti-hypertensive, anti-oxidative, immunomodulant, anti-mutagenic, anti- 
microbial, opioid, anti-thrombotic, antiobesity, and mineral-binding agents. It has been reported that many bioactive peptides help against inflammatory bowel disease in mice (Jayatilake et al., 2014).

Recently, whey proteins have been used in many foods, including ice cream, bread, and infant formula; moreover, whey proteins can replace fat in many products (Hammam and Ahmed, 2019). Furthermore, these dairy products are also associated with lower risks of hypertension, coagulopathy, stroke, and cancer insurgences (Sultan et al., 2018). Additionally, whey proteins have a significant role in muscle-structure complement (Lollo et al., 2011; Josse and Phillips, 2013). Whey proteins also have other applications, such as films and coatings (Hammam, 2019a) that are widely used to enhance the texture and quality of several foods. This work aims to review and highlight whey protein products and functional properties. Furthermore, the health benefits and applications of whey proteins are also discussed in this review.

\section{Types of whey}

Milk consists of fat globules and casein micelles that dispersed in the whey solution (Figure 1). The typical composition of whey compared to whole milk is shown in Table 1. Whey is a yellowish or greenish by-product that derived from coagulating the milk by using rennet or acid. As a result, the whey is defined as sweet or acid based on the coagulation method. The composition of sweet whey and acid whey is quietly similar (Table 2) except for lactose, calcium, and $\mathrm{pH}$. In the acid whey case, the $\mathrm{pH}$ is decreased during fermentation until the isoelectric point ( $\mathrm{pH}=4.6$ ), and this, in turn, converts the calcium in calcium casein phosphate complex from insoluble to soluble, which resulted in higher calcium content in the acid whey. Lactose is a soluble component and represents
$>69 \%$ of the total solids, while minerals represent $12-15 \%$ and whey protein or serum protein $8-10 \%$ of the total solids.

\section{Manufacturing and applications of whey protein products}

Whey protein can be utilized to produce many products that have many applications (Figure 2). As mentioned, there are two types of permeate, namely sweet whey and acid whey. Acid whey is a by-product which is more difficult to utilize and produced from the coagulation of milk by using acid or starter cultures without the use of rennet. On the other hand, sweet whey has advantages as compared to acid whey, since sweet whey (milk-derived whey protein) can be utilized in many applications, particularly making whey protein isolate (WPI).

Nowadays, membrane technology (Figure 3) is utilized widely in the dairy industry to fractionate dairy ingredients, which led to several whey protein products (Table 3). When microfiltration (MF) applied to milk; casein and permeate are fractionated. The MF permeate could be further concentrated by using ultrafiltration (UF) to produce whey protein concentrate (WPC) or whey protein (WP) and permeate as a by-product. The UF permeate could be used to produce fermentation products, or it could be further nanofiltered (NF) to fractionate lactose. The NF by-product could be filtered again by using reverse osmosis (RO) to separate the minerals from the water. These membranes could be used individually or combined based on the required permeate product and its application (Table 4).

\section{Chemistry of whey proteins}

Milk is utilized as feeding for young animals and humans due to the nutritional value of whey protein (Miller et al., 2002). 
Bovine milk contains approximately 3\% protein (Fox and McSweeney, 1998), which divided into $80 \%$ casein $(\mathrm{CN})$ and $20 \%$ whey proteins (Pihlanto and Korhonen, 2003). Whey protein has different fractions, including $\beta$-lactoglobulin ( $\beta$-LG) and $\alpha$ lactalbumin ( $\alpha$-LA), which are the majority of whey proteins and represent $70-80 \%$ of the whey protein. Also, there is proteose-peptone that resulted from the proteolysis $\beta$-casein ( $\beta$ $\mathrm{CN}$ ); besides small amounts of bovine serum albumin, immunoglobulins (Ig), and small peptides (Whitney, 1988a; Miller et al., 2002). The amino acid profiles in whey proteins are completely different from casein due to their lower content of Glu and Pro and higher amount of sulfur-containing amino acid residues (such as Cys and Met).

These proteins are dephosphorylated, sensitive to high temperature, insensitive to $\mathrm{Ca}^{2+}$, and liable to the intermolecular bond formation through disulfide bonds between cysteine sulfhydryl groups.

Table.1 The composition of whole milk and whey.

Adapted from (Smithers, 2008; Côrtes et al., 2010; Hammam et al., 2017)

\begin{tabular}{|l|c|c|}
\hline \multirow{2}{*}{ Components } & \multicolumn{2}{|c|}{ Weight (\%) } \\
\cline { 2 - 3 } & Whole milk & Whey \\
\hline Total solids & $11.5-12.8$ & $6.3-7.0$ \\
\hline Lactose & $4.6-4.9$ & $4.4-4.6$ \\
\hline Casein & $2.5-2.8$ & $<0.1$ \\
\hline Whey protein & $0.6-0.7$ & $0.6-0.8$ \\
\hline Fat & $3.0-3.7$ & 0.1 \\
\hline Ash & $0.6-0.7$ & 0.5 \\
\hline
\end{tabular}

Table.2 Typical composition of sweet and acid whey. Adapted from (Tunick, 2008a; Hammam et al., 2017; Hammam, 2019a)

\begin{tabular}{|l|c|c|}
\hline \multirow{2}{*}{ Components } & \multicolumn{2}{|c|}{ Weight (\%) } \\
\cline { 2 - 3 } Total solids & Sweet whey & Acid whey \\
\hline Lactose & $6.3-7.0$ & $6.3-7.0$ \\
\hline Protein & $4.6-5.2$ & $4.4-4.6$ \\
\hline Calcium & $0.6-1.0$ & $0.6-0.8$ \\
\hline Phosphate & $0.04-0.06$ & $0.12-0.16$ \\
\hline Chloride & $0.1-0.3$ & $0.2-0.45$ \\
\hline pH & 0.11 & 0.11 \\
\hline
\end{tabular}


Table.3 Typical composition of whey products; Adapted from (Yalcin, 2006; Tunick, 2008a; Hammam et al., 2017; Guo and Wang, 2019b; Hammam, 2019a)

\begin{tabular}{|l|c|c|c|c|c|}
\hline \multirow{2}{*}{ Product } & \multicolumn{4}{|c|}{ Weight (\%) } \\
\cline { 2 - 6 } & Protein & Lactose & Fat & Ash & Moisture \\
\hline Sweet whey powder & $11.0-14.5$ & $63.0-75.0$ & $1.0-1.5$ & $8.2-8.8$ & $3.5-5.0$ \\
\hline Acid whey powder & $11.0-13.5$ & $61.0-70.0$ & $0.5-1.5$ & $9.8-12.3$ & $3.5-5.0$ \\
\hline Demineralized whey & $11.0-15.0$ & $70.0-80.0$ & $0.5-1.8$ & $1.0-7.0$ & $3.0-4.0$ \\
\hline WPC (34\% protein) & $34.0-36.0$ & $48.0-52.0$ & $3.0-4.5$ & $6.5-8.0$ & $3.0-4.5$ \\
\hline WPC (60\% protein) & $60.0-62.0$ & $25.0-30.0$ & $1.0-7.0$ & $4.0-6.0$ & $3.0-5.0$ \\
\hline WPC (80\% protein) & $80.0-82.0$ & $4.0-8.0$ & $4.0-8.0$ & $3.0-4.0$ & $3.5-4.5$ \\
\hline WPI & $90.0-92.0$ & $0.5-1.0$ & $0.5-1.0$ & $2.0-3.0$ & $3.0-5.0$ \\
\hline
\end{tabular}

$\mathrm{WPC}=$ Whey protein concentrate; $\mathrm{WPI}=$ Whey protein isolate

Table.4 Application of whey proteins in dairy-based foods; Adapted from (Mulvihill and Ennis, 2003)

\begin{tabular}{|c|c|}
\hline Product & The benefit of whey products \\
\hline Yogurt, cheese (Quarg, Ricotta) & $\begin{array}{l}\text { Yield; nutritional, consistency, curd } \\
\text { cohesiveness }\end{array}$ \\
\hline $\begin{array}{l}\text { Cream cheese and cheese spreads, } \\
\text { sliceable/squeezable cheeses, cheese filling and } \\
\text { dips }\end{array}$ & Emulsifier, gelling, sensory properties \\
\hline $\begin{array}{l}\text { Soft drinks, fruit juices, powdered or frozen } \\
\text { orange beverages }\end{array}$ & Nutritional \\
\hline Milk-based flavored beverages & Viscosity, colloidal stability \\
\hline $\begin{array}{l}\text { Ice cream, frozen desserts coating, frozen juice } \\
\text { bars }\end{array}$ & $\begin{array}{l}\text { Skimmed milk solid replacement, whipping } \\
\text { properties, emulsifying properties, body and } \\
\text { texture }\end{array}$ \\
\hline
\end{tabular}

Table.5 The chemical and physiological properties of whey protein fractions and their relative molecular weight. Adapted from (Whitney, 1988b; Zydney, 1998;

Hammam et al., 2017; Hammam, 2019a)

\begin{tabular}{|l|c|c|c|}
\hline $\begin{array}{l}\text { Whey protein } \\
\text { fractions }\end{array}$ & Concentration (g/L) & MW (kDa) & Isoelectric point (pI) \\
\hline $\boldsymbol{\beta}$-Lactoglubilin & $3.0-4.0$ & 18.4 & 5.2 \\
\hline $\boldsymbol{\alpha}$-Lactalbumin & $0.7-1.5$ & 14.2 & $4.7-5.1$ \\
\hline $\begin{array}{l}\text { Bovine serum } \\
\text { albumin }\end{array}$ & $0.3-0.6$ & 69 & $4.7-4.9$ \\
\hline IgG, IgA, IgM & $0.6-0.9$ & $150-1000$ & $5.5-8.3$ \\
\hline Lactoperoxidase & 0.006 & 89 & 9.6 \\
\hline Lactoferrin & $0.05-0.35$ & 78 & 8.0 \\
\hline Protease-peptone & $0.5-1.0$ & $4-20$ & \\
\hline Caseinomacropeptide & $0.0-1.5$ & 7 & \\
\hline
\end{tabular}




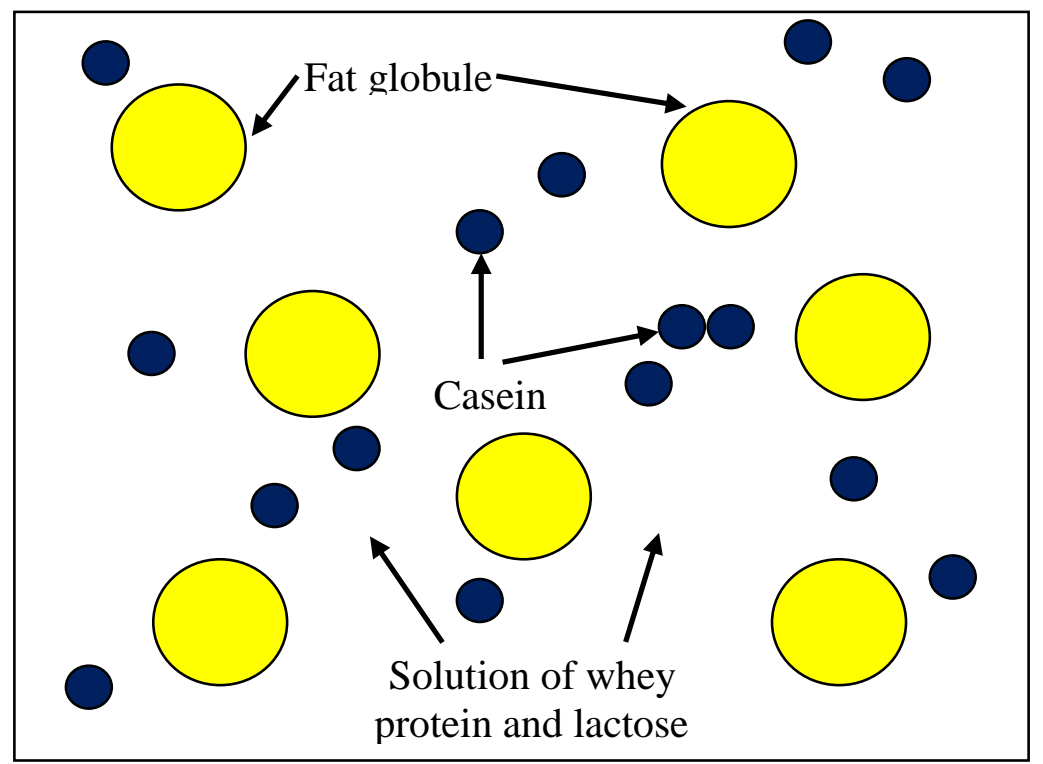

Figure.1 Milk contains fat globules and casein micelles colloidal in a solution of whey protein and lactose

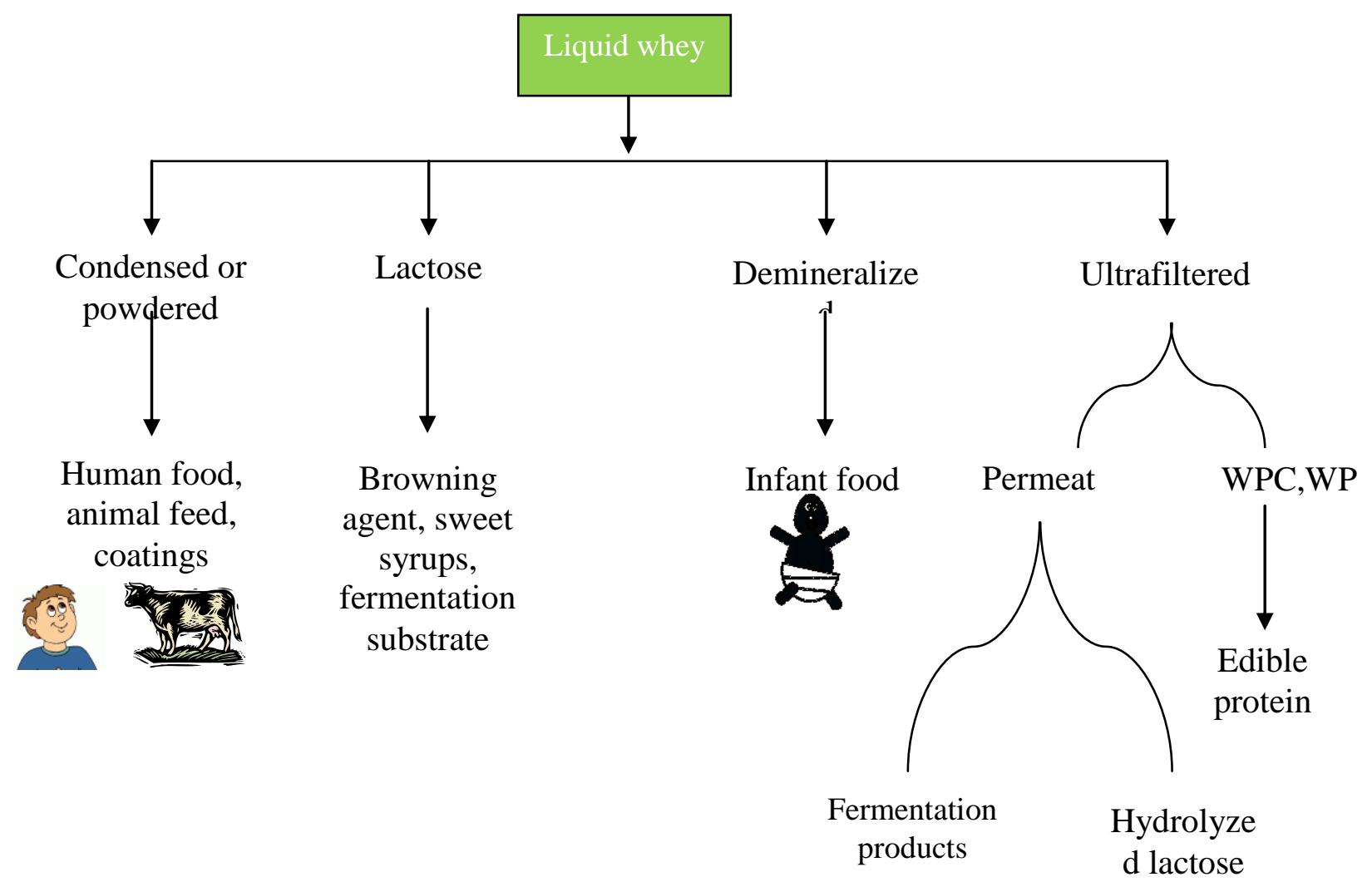

Figure.2 Liquid whey processing (Marwaha and Kennedy, 1988; Siso, 1996; Tunick, 2008b) 


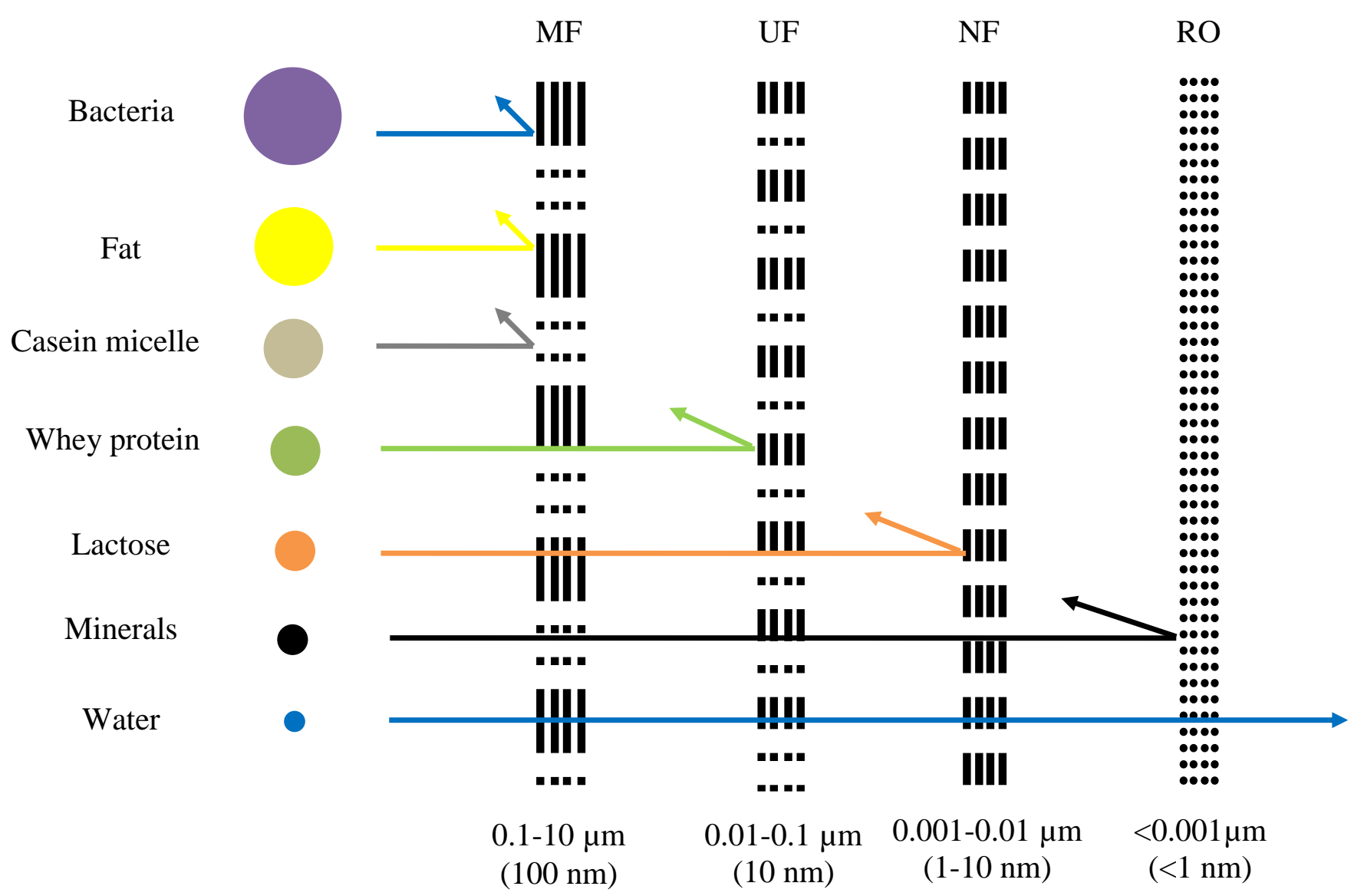

Figure.3 Filtration spectrum and size of major components in milk

Therapeutic applications of whey proteins

Whey protein has a high amount of bioactive components, including $\alpha$-lactalbumin, $\beta$ lactoglobulin, bovine serum albumin, immunoglobulins, lactoferrin, and lactoperoxidase (Table 5). These proteins have been used as ingredients in pharmaceuticals, nutraceuticals, and cosmeceuticals applications (Pihlanto and Korhonen, 2003; Etzel, 2004) due to their bioactive characteristics (Korhonen and Pihlanto, 2003). Many studies have been reported that these bioactive peptides have many health benefits, such as improving the immune system (Mann et al., 2019), inhibiting infections due to the antiviral activity of lactoferrin (Drago-Serrano et al., 2017; Hammam, 2019b), reducing oxidative stress and human immunodeficiency virus (HIV) infection (Gupta and Prakash, 2017), anticancer activity (Patel, 2015; Hammam et al., 2017), lessen anxiety (Yalcin, 2006), assist with the reduction in blood pressure (Fekete et al., 2018), positive effects on hepatitis (Ng et al., 2015), reduce cardiovascular risk (Pal et al., 2019), and osteoporosis (Mangano et al., 2019).

Nutritional applications of whey protein products

Whey protein products are widely used in many applications, including infant formulas, 
dietetic foods, and animal feeds (Fitzsimons et al., 2008). Polymerized whey protein, which has different commercial names, such as preheated whey protein, process whey protein, heat-denatured whey proteins, or denatured whey proteins (Vardhanabhuti et al., 2001), has shown improved functional properties, including gelatin agents, films (Hammam, 2019a), thickness agents, stabilizers, microencapsulation, and coatings that are widely used to enhance the texture and quality of several foods, such as sausages, dairy products, desserts, bakery products, cold sauces (Elofsson et al., 1997; Hammam, 2019a), beverages, bars, and fruits (Ferreira $e t$ al., 2007).

Milk whey or whey protein has tremendous therapeutic properties, including antimicrobial, anticancer, anticarcinogenic effects, immune-enhancer, prebiotic property, anti-inflammatory, anti-hypertensive actions, binding of toxins, cardiovascular, antioxidant activity, gastro-intestinal health, physical strength, obesity control and weightmanagement, HIV, diabetes, anti-viral effects, promotion of cell growth, platelet binding, appetite suppression, ageing, and wound healing. Several whey products are available nowadays in the market, which can be utilized as attractive health-promoting food supplements.

\section{References}

Côrtes, C., D.C. da Silva-Kazama, R. Kazama, N. Gagnon, C. Benchaar, G.T.D. Santos, L.M. Zeoula, and H.V. Petit. 2010. Milk composition, milk fatty acid profile, digestion, and ruminal fermentation in dairy cows fed whole flaxseed and calcium salts of flaxseed oil. J. Dairy Sci. 93:3146-3157. doi:10.3168/jds.2009-2905.

Drago-Serrano, M., R. Campos-Rodríguez, J. Carrero, and M. de la Garza. 2017.
Lactoferrin: Balancing Ups and Downs of Inflammation Due to Microbial Infections. Int. J. Mol. Sci. 18:501. doi:10.3390/ijms18030501.

Elofsson, C., P. Dejmek, M. Paulsson, and H. Burling. 1997. Characterization of a cold-gelling whey protein concentrate. Int. Dairy J. 7:601-608. doi:10.1016/S0958-6946(97)00050-2.

Etzel, M.R. 2004. Manufacture and Use of Dairy Protein Fractions. J. Nutr. 134:996S-1002S. doi:10.1093/jn/134.4.996S.

Fekete, Á.A., C. Giromini, Y. Chatzidiakou, D.I. Givens, and J.A. Lovegrove. 2018. Whey protein lowers systolic blood pressure and $\mathrm{Ca}$-caseinate reduces serum TAG after a high-fat meal in mildly hypertensive adults. Sci. Rep. 8:5026. doi:10.1038/s41598-01823333-2.

Ferreira, I.M.P.L.V.O., O. Pinho, M.V. Mota, P. Tavares, A. Pereira, M.P. Gonçalves, D. Torres, C. Rocha, and J.A. Teixeira. 2007. Preparation of ingredients containing an ACE-inhibitory peptide by tryptic hydrolysis of whey protein concentrates. Int. Dairy J. 17:481-487. doi:10.1016/j.idairyj.2006.06.023.

Fitzsimons, S.M., D.M. Mulvihill, and E.R. Morris. 2008. Large enhancements in thermogelation of whey protein isolate by incorporation of very low concentrations of guar gum. Food Hydrocoll. 22:576-586. doi:10.1016/j.foodhyd.2007.01.013.

Fox, P.F., and P.L.H. McSweeney. 1998. Dairy Chemistry and Biochemistry. Kluwer Academic/Plenum Publishers.

Guo, M., and G. Wang. 2019a. History of Whey Production and Whey Protein Manufacturing. Wiley Online Books.

Guo, M., and G. Wang. 2019b. History of Whey Production and Whey Protein Manufacturing. Wiley Online Books.

Gupta, C., and D. Prakash. 2017. Therapeutic 
Potential of Milk Whey. Beverages 3:31. doi:10.3390/beverages3030031.

Hammam, A.R.A. 2019a. Technological, applications, and characteristics of edible films and coatings: a review. $\mathrm{SN}$ Appl. Sci. 1:632. doi:10.1007/s42452019-0660-8.

Hammam, A.R.A. 2019b. Compositional and Therapeutic Properties of Camel Milk: A Review. Emirates J. Food Agric. $31: 148$. doi:10.9755/ejfa.2019.v31.i3.1919.

Hammam, A.R.A., and M.S.I. Ahmed. 2019. Technological and Characteristics of Low-Fat Cheeses: A Review. Assiut J. Agric. Sci. 50:15-27. doi:10.21608/ajas.2019.33455.

Hammam, A.R.A., A.A. Tammam, Y.M.A. Elderwy, and A.I. Hassan. 2017. Functional Peptides in Milk Whey: An Overview. Assiut J. Agric. Sci. 48:7791. doi:10.21608/ajas.2017.19875.

Jayatilake, S., K. Arai, N. Kumada, Y. Ishida, I. Tanaka, S. Iwatsuki, T. Ohwada, M. Ohnishi, Y. Tokuji, and M. Kinoshita. 2014. The effect of oral intake of lowtemperature-processed whey protein concentrate on colitis and gene expression profiles in mice. Foods 3:351-368.

doi:https://doi.org/10.3390/foods302035 1.

Josse, A.R., and S.M. Phillips. 2013. Impact of Milk Consumption and Resistance Training on Body Composition of Female Athletes. M. Lamprecht, ed.

Korhonen, H., and A. Pihlanto. 2003. Foodderived Bioactive Peptides Opportunities for Designing Future Foods. Curr. Pharm. Des. 9:1297-1308. doi:10.2174/1381612033454892.

Lollo, P., J. Amaya-Farfan, and L. de Carvalho-Silva. 2011. Physiological and physical effects of different milk protein supplements in elite soccer players. J. Hum. Kinet. 30:49-57.
Mangano, K.M., Y. Bao, and C. Zhao. 2019. Nutritional Properties of Whey Proteins. Wiley Online Books. John Wiley \& Sons, Ltd, Chichester, UK.

Mann, B., S. Athira, R. Sharma, R. Kumar, and P. Sarkar. 2019. Chapter 14 Bioactive Peptides from Whey Proteins. H.C. Deeth and N.B.T.-W.P. Bansal, ed. Academic Press.

Marwaha, S.S., and J.F. Kennedy. 1988. Whey-pollution problem and potential utilization. Int. J. Food Sci. Technol. 23:323-336. doi:10.1111/j.13652621.1988.tb00586.x.

Miller, G.D., J.K. Jarvis, and L.D. McBean. 2002. Handbook of Dairy Foods and Nutrition. Third edit. CRC press.

Mulvihill, D.M., and M.P. Ennis. 2003. Functional Milk Proteins: Production and Utilization. P.F. Fox, ed. Springer US, Boston, MA.

Ng, T.B., R.C.F. Cheung, J.H. Wong, Y. Wang, D.T.M. Ip, D.C.C. Wan, and J. Xia. 2015. Antiviral activities of whey proteins. Appl. Microbiol. Biotechnol. 99:6997-7008. doi:10.1007/s00253015-6818-4.

Pal, S., J. McKay, M. Jane, and S. Ho. 2019. Dairy Whey Proteins and Obesity. R.R.B.T.-N. in the P. and T. of A.O. (Second E. Watson, ed. Elsevier.

Patel, S. 2015. Emerging trends in nutraceutical applications of whey protein and its derivatives. J. Food Sci. Technol. 52:6847-6858 doi:10.1007/s13197-015-1894-0.

Pihlanto, A., and H. Korhonen. 2003. Bioactive peptides and proteins. S. Taylor, ed. Academic Press.

Siso, M.I.G. 1996. The biotechnological utilization of cheese whey: a review. Bioresour. Technol. 57:1-11.

Smithers, G.W. 2008. Whey and whey proteins-from 'gutter-to-gold'. Int. Dairy J. 18:695-704.

Sultan, S., N. Huma, M.S. Butt, M. Aleem, 
and M. Abbas. 2018. Therapeutic potential of dairy bioactive peptides: A contemporary perspective. Crit. Rev. Food Sci. Nutr. 58:105-115. doi:10.1080/10408398.2015.1136590.

Tunick, M.H. 2008a. Whey Protein Production and Utilization: A Brief History. C.I. Onwulata and P.J. Huth, ed. Wiley Online Books.

Tunick, M.H. 2008b. Whey Protein Production and Utilization: A Brief History. C.I. Onwulata and P.J. Huth, ed. Wiley Online Books. WileyBlackwell, Oxford, UK.

Vardhanabhuti, B., E.A. Foegeding, M.K. McGuffey, C.R. Daubert, and H.E. Swaisgood. 2001. Gelation properties of dispersions containing polymerized and native whey protein isolate. Food Hydrocoll.
doi:10.1016/S0268-005X(00)00062-X. Whitney, R.M. 1988a. Proteins of Milk BT Fundamentals of Dairy Chemistry. N.P. Wong, R. Jenness, M. Keeney, and E.H. Marth, ed. Springer US, Boston, MA.

Whitney, R.M. 1988b. Proteins of Milk BT Fundamentals of Dairy Chemistry. N.P. Wong, R. Jenness, M. Keeney, and E.H. Marth, ed. Springer US, Boston, MA.

Yalcin, A.S. 2006. Emerging therapeutic potential of whey proteins and peptides. Curr. Pharm. Des. 12:1637-1643. doi:https://doi.org/10.2174/1381612067 76843296

Zydney, A.L. 1998. Protein Separations Using Membrane Filtration: New Opportunities for Whey Fractionation. Int. Dairy J. 8:243-250. doi:10.1016/S0958-6946(98)00045-4.

\section{How to cite this article:}

Mahmoud E. Ahmed, Ahmed M. Hamdy and Ahmed R. A. Hammam. 2020. Therapeutic Benefits and Applications of Whey Protein. Int.J.Curr.Microbiol.App.Sci. 9(07): 337-345. doi: https://doi.org/10.20546/ijcmas.2020.907.036 